\title{
PENDAMPINGAN PELATIHAN KETERAMPILAN - PEMANFAATAN SAMPAH BUNGKUS MINUMAN MENJADI BARANG BERNILAI EKONOMI Bagi Kelompok Ibu Rumah Tangga (PKK) RW 05 Kelurahan Bukit Tempayan Batam
}

\author{
TRAINING ASSISTANCE-AN UTILIZING DRINK PACK WASTES BEING \\ VELUABLE PRODUCT \\ (for housewive Community at RW 05 Bukit Tempayang Sub-District, Batam)
}

\author{
Ravika Permata Hati ${ }^{1}$, Muhammad Hidayat ${ }^{2}$ \\ ${ }^{1,2}$ Prodi Akuntansi, Fakultas Ekonomi, \\ Universitas Riau Kepulauan, Batam, Indonesia \\ ${ }^{1}$ ravika@fekon.unrika.ac.id, ${ }^{2}$ mhidayatb@fekon.unrika.ac.id
}

\begin{abstract}
Abstrak
Pengabdian masyarakat ini bertujuan untuk meningkatkan pengetahuan masyarakat tentang pengolahan sampah bungkus minuman menjadi barang bernilai guna (ekonomis) dan memberdayakan masyarakat untuk melakukan pengolahan tersebut sehingga bisa menambah pendapatan mereka. Kegiatan ini melibatkan ibu rumah tangga (PKK) RW 05 Kelurahan Bukit Tempayan, Kecamatan Batu Aji, Batam. Kegiatan pengabdian masyarakat ini dilakukan selama 3 hari dengan jumlah peserta sebanyak 30 orang. Metode kegiatan ini adalah dengan cara ceramah atau presentasi dan demonstrasi langsung kepada peserta. Kegiatan pengabdian masyarakat ini dinilai berhasil yang dilihat dari kepuasan peserta setelah mengikuti pelatihan. Selain itu, peserta berpendapat bahwa mereka memperoleh ilmu baru dan berharap pelatihan ini dapat berkelanjutan.
\end{abstract}

Kata Kunci: pengolahan sampah; sampah bungkus minuman; pengetahuan; pendapatan

\begin{abstract}
This community service program aims to improve knowledge of citizen about how to utilize drink packs wastes being veluable product product and to empower citizen to recycle the wastes to increase their incomes. This activity involved the community of housewife at RW 05 Bukit Tempayan, Batu Aji district. This community service program was conducted for three days with 30 participants. The methods of this program included: presentation and workshop to participants. This activity was succeed due to citizens' satisfaction after joining this program. Beside it, participants assumed that they got new knowledge and hoped it became a continue activity.
\end{abstract}

Keywords: wastes utilizing, drink pack waste, knowledge, income 


\section{PENDAHULUAN}

Sampah merupakan salah satu permasalahan lingkungan yang memerlukan penanganan serius. Berdasarkan Undang-Undang No. 18 Tahun 2008, sampah adalah sisa kegiatan sehari-hari manusia dan atau proses alam yang berbentuk padat. Secara umum sampah dibedakan menjadi tiga, yaitu sampah organik/basah, sampah anorganik/kering, dan sampah berbahaya (Kuncoro Sejati, 2009: 15). Seiring dengan meningkatnya jumlah penduduk di suatu wilayah maka juga mengakibatkan bertambahnya volume sampah. Pola konsumsi masyarakat ikut memberi kontribusi dalam peningkatan volume sampah yang semakin beragam jenisnya. Sampah rumah tangga merupakan salah satu sumber sampah yang cukup besar peranannya dalam peningkatan volume sampah di suatu lingkungan.

Pengelolaan sampah masih kurang mendapat penanganan yang optimal dari berbagai pihak, baik dari masyarakat setempat maupun pemerintah daerah. Penanganan yang kurang optimal akan menimbulkan berbagai permasalahan lingkungan, seperti timbulnya banjir, timbulnya penyakit, sanitasi lingkungan memburuk, turunnya kandungan organik lahan pertanian, dan mempercepat terjadinya pemanasan global. Oleh karena itu diperlukan adanya komitmen bersama dalam pengelolaan sampah sehingga tidak menimbulkan berbagai permasalahan lingkungan.

Peran masyarakat dalam pengelolaan sampah diperlukan tidak hanya sebatas dalam membuang sampah di tempat yang seharusnya, namun diharapkan termasuk juga pengolahan sampah yang memberikan manfaat kembali bagi masyarakat itu sendiri. Dalam hal ini sebagai salah satu bentuk tanggung jawab dosen dalam melaksanakan tridarma perguruan tinggi maka perlu diadakan pengabdian pada masyarakat berupa pelatihan pengelolaan sampah rumah tangga dengan pemanfaatan barang bekas atau sampah menjadi barang yang bernilai guna. Dengan adanya pelatihan ini dihaharapkan sampah rumah tangga seperti botol air mineral, bungkus detergen, makanan, minuman, dan sebagainya dapat dijadikan sebuah produk yang bernilai guna, bahkan dapat dijual kepada konsumen yang tertarik untuk menggunakannya.

Perempuan memiliki peran penting dalam pengelolaan sampah rumah tangga, terkait salah satu perannya sebagai ibu rumah tangga. Kelurahan Bukit Tempayan khususnya ibu-ibu rumah tangga RW 05 memiliki kegiatan rutin pertemuan ibu-ibu pengurus PKK di tingkat kelurahan. Diharapkan dengan adanya pelatihan bagi ibu-ibu PKK tentang pengelolaan sampah rumah tangga dengan pemanfaatan barang bekas atau sampai menjadi barang yang 
bernilai guna yang dikemas dalam paket pengabdian masyarakat oleh Tim dosen Program Studi Akuntansi Universitas Riau Kepulauan, maka dapat ditularkan kepada ibu-ibu di lingkungan sekitarnya sehingga akan sangat membantu dalam menjaga kebersihan lingkungan, mengurangi volume sampah yang dibuang ke lingkungan dan meningkatkan keahlian dan pendapatan.

\section{Lingkungan Hidup}

Menurut Undang-Undang Republik Indonesia No. 32 Tahun 2009 tentang Perlindungan dan Pengelolaan Lingkungan Hidup, batasan Lingkungan Hidup seperti tertera dalam pasal 1 ayat (1), yaitu: kesatuan ruang dengan semua benda, daya, keadaan, dan makhluk hidup termasuk manusia dan perilakunya, yang mempengaruhi alam itu sendiri, kelangsungan perikehidupan, dan kesejahteraan manusia serta makhluk hidup lain.

\section{Sampah}

Sampah merupakan suatu bahan yang terbuang atau dibuang dari sumber hasil aktivitas manusia maupun proses alam yang belum memiliki nilai ekonomis (Damanhuri, E., dkk., 2004). Sampah adalah suatu benda yang tidak digunakan atau tidak dikehendaki dan harus dibuang, yang dihasilkan oleh kegiatan manusia (Karden Edy Sontang Manik, 2007: 67). Sampah secara umum diklasifikasikan menjadi dua, yaitu 1) sampah organik yang merupakan sampah yang dapat terurai atau membusuk secara alamiah, misalnya sisa sayursayuran, buah-buahan, dan daun-daunan; 2) sampah anorganik, sampah yang tidak dapat terurai atau membusuk secara alamiah dan memerlukan waktu yang sangat lama sekali untuk terurai, contoh kertas, plastik minuman dan makanan, kayu-kayuan, dll.

\section{Pengelolaan Sampah}

Sampah yang dikelola berdasarkan Undang-Undang Republik Indonesia Nomor 18 Tahun 2008, terdiri dari: 1) sampah rumah tangga, sampah yang berasal dari kegiatan seharihari dalam rumah tangga, tidak termasuk tinja dan sampah spesifik.; 2) Sampah sejenis sampah rumah tangga, yaitu sampah yang berasal dari kawasan komersial, kawasan industri, kawasan khusus, fasilitas sosial, fasilitas umum, dan/atau fasilitas lainnya; 3) sampah spesifik, yang meliputi sampah yang mengandung bahan berbahaya dan beracun sampah yang mengandung limbah bahan berbahaya dan beracun,s ampah yang timbul akibat bencana, puing bongkaran bangunan, sampah yang secara teknologi belum dapat diolah sampah yang timbul secara tidak periodik. 
Beberapa permasalahan yang teridentifikasi di lokasi pengabdian sehingga dirasa penting untuk segera dilakukan pelatihan, antara lain: a) Peningkatan volume sampah seiring meningkatnya jumlah penduduk; b) Pola konsumsi masyarakat yang mempengaruhi peningkatan volume sampah. c) adanya variasi jenis sampah; d) pengelolaan sampah masih kurang mendapat penanganan yang optimal sehingga menimbulkan berbagai permasalahan lingkungan; e) peran masyarakat dalam pengelolaan sampah kebanyakan masih sebatas membuang sampah di tempat yang seharusnya atau belum pada pengolahan sampah yang memberikan manfaat kembali bagi masyarakat; f) masih rendahnya pengetahuan masyarakat tentang pengelolaan sampah rumah tangga dengan pemanfaatan sampah bungkus minuman menjadi barang bernilai guna; g) masyarakat belum diberdayakan dalam pengelolaan sampah rumah tangga dengan keterampilan pemanfaatannya.

Berdasarkan pertimbangan urgensi permasalahan yang teridentifikasi di atas, maka dipilih dua masalah yang hendak dicari solusinya melalui kegiatan pelatihan ini. Dari masalah-masalah tersebut dapat dirumuskan masalah sebagai berikut: (a) bagaimana meningkatkan pengetahuan masyarakat tentang pengelolaan sampah bungkus minuman menjadi barang bernilai guna? (b) bagaimana memberdayakan ibu rumah tangga dalam pemanfaatan sampah bungkus minuman menjadi barang bernilai guna sehingga bisa menambah pendapatan mereka?

Tujuan diselenggarakannya kegiatan pengabdian kepada masyarakat ini adalah: Meningkatkan pengetahuan masyarakat tentang pengelolaan sampah bungkus minuman menjadi barang bernilai ekonomis dan memberdayakan masyarakat dalam pengelolaan sampah bungkus minuman menjadi barang bernilai guna sehingga bisa menambah pendapatan mereka.

Manfaat yang diharapkan dari kegiatan pengabdian kepada masyarakat ini adalah: Sebagai wahana untuk meningkatkan pengetahuan dan wawasan masyarakat khalayak sasaran dalam pengelolaan sampah rumah tangga seperti sampah bungkus minuman menjadi barang bernilai guna. Memberikan alternatif pengelolaan sampah rumah tangga di daerah pengabdian, yang secara tidak langsung juga memberdayakan masyarakat di lokasi pengabdian untuk memanfaatkan sampah sehingga dapat digunakan atau dijual ke konsumen. Meningkatkan kesadaran masyarakat di daerah pengabdian tentang pentingnya pengelolaan sampah rumah tangga dengan keterampilan untuk menjaga kelestarian lingkungan serta 
sebagai forum untuk bertukar pikiran antara pihak masyarakat dan pamong setempat dengan perguruan tinggi dalam hal pengelolaan sampah rumah tangga dengan memanfaatkan sampah bungkus minuman.

\section{METODOLOGI}

\section{Sasaran Kegiatan}

Sasaran kegiatan pengabdian ini adalah masyarakat di RW 05 Kelurahan Bukit Tempayan, Kecamatan Batu Aji, Kota Batam . Masyarakat yang diundang dalam kegiatan pelatihan ini sesuai dengan tujuan kegiatan PPM adalah ibu-ibu rumah tangga yang masuk kedalam anggota PKK masing-masing RT di RW 05 Kelurahan Bukit Tempayan berdasarkan arahan dari pamong setempat dan jumlahnya sebanyak 30 orang.

Metode kegiatan pengabdian yang digunakan, yaitu:

1. Ceramah

Metode ceramah dipilih untuk menyampaikan konsep tentang lingkungan hidup, klasifikasi sampah, peran serta perempuan dalam pengelolaan lingkungan hidup, serta pengelolaan sampah rumah tangga tentang kerajinan dari sampah bungkus minuman. Apabila peserta pelatihan tidak jelas dengan materi yang disampaikan oleh narasumber dapat memberikan pertanyaan secara langsung atau tidak harus menunggu sesi tanya jawab. Penggunaan metode ceramah dikombinasikan dengan memanfaatkan laptop dan LCD untuk menayangkan materi powerpoint yang dilengkapi dengan gambar-gambar, termasuk penayangan video pemanfaatan kerajinan sampah bungkus minuman. Pemanfaatan laptop dan LCD membantu peserta pelatihan lebih mudah memahami pengelolaan sampah di lingkungan, mengingat materi pelatihan relatif banyak dan waktu pelatihan yang terbatas.

2. Demonstrasi

Metode demonstrasi dipilih untuk menunjukkan suatu proses kerja sehingga dapat memberikan kemudahan bagi peserta pelatihan. Demonstrasi dilakukan oleh tim pengabdi sebagai nara sumber dengan harapan peserta pelatihan dapat melaksanakan simulasi secara sempurna pemanfaatan sampah bungkus minuman dengan kerajinan tangan sesuai dengan petunjuk yang telah diberikan oleh narasumber.

\section{Langkah-langkah Kegiatan}

Langkah-langkah kegiatan dalam pengabdian ini melalui tahapantahapan berikut ini: 
1. Ceramah tentang lingkungan hidup

2. Ceramah tentang klasifikasi sampah.

3. Ceramah tentang peran serta perempuan dalam pengelolaan lingkungan hidup.

4. Ceramah tentang pemanfaatan sampah rumah tangga dengan metode kerajinan tangan.

5. Diskusi atau tanya jawab mengenai hal-hal yang berkaitan dengan sampah rumah tangga dan pengelolaannya.

6. Demonstrasi tentang pengelolaan sampah rumah tangga dengan metode kerajinan tangan.

7. Latihan membuat kerajinan tangan berupa tas dan dompet yang berasal dari sampah bungkus minuman.

\section{Faktor Pendukung dan Penghambat Kegiatan}

Berdasarkan evaluasi pelaksanaan kegiatan, dapat diidentifikasi faktor-faktor pendukung dan penghambat dalam pelaksanaan program pengabdian ini, antara lain:

1. Faktor Pendukung

a. Ibu PKK RW 05 mau diajak untuk bekerja sama dan sangat membantu pelaksanaan kegiatan pengabdian.

b. Antusiasme perempuan di lokasi pengabdian dalam mengikuti program pengabdian yang dilakukan.

2. Faktor Penghambat

Satu-satunya faktor penghambat dalam proses kegitan pengabdian ini adalah keterbatasan waktu pelaksanaan pengabdian.

\section{Waktu dan Tempat Pelaksanaan Kegiatan}

Kegiatan pengabdian ini dilakukan pada:

Hari/tanggal: - Minggu/ 20 Agustus 2017

- Sabtu/ 26 Agustus 2017

- Minggu/27 Agustus 2017

Tempat: $\quad$ Posyandu Melati V RW 05 Bukit Tempayan

\section{PEMBAHASAN}

\section{Hasil Pelaksaan Kegiatan Abdimas}

Adapun garis besar hasil pelaksanaan kegiatan Abdimas adalah sebagai berikut: 
1. Langkah awal kegiatan Abdimas, yaitu penyampaian gagasan pelaksanaan pengabdian kepada Bapak RW 05 Bukit Tempayan agar dapat berjalan lancar, sehingga ibu-ibu rumah tangga yang ada di RW 05 Bukit Tempayan siap menerima kedatangan tim Abdimas Unrika untuk melaksanakan program pengabdian.

2. Hasil pelaksanaan pelatihan pemanfaatan kerajinan pada sampah bungkus minuman melibatkan ibu-ibu rumah tangga RW 05 Bukit Tempayan sebagai berikut:

a. Kegiatan pengabdian dilaksanakan pada hari Minggu, tanggal 20 Agustus 2017, Sabtu 26 Agustus 2017 dan berakhir pada hari Minggu 27 Agustus 2017 . Kegiatan tersebut dihadiri 30 orang peserta atau semua peserta yang diundang hadir dan peserta menunjukkan antusiasme cukup besar terhadap program pengabdian dari tim Abdimas Unrika.

b. Materi pelatihan dapat semuanya disampaikan oleh tim Abdimas Unrika, meskipun tidak disampaikan secara detil. Tim Abdimas Unrika mengundang narasumber ahli untuk memaparkan lebih detail tentang bagaimana pemanfaatan kerajinan dari sampah bungkus minuman tersebut.

c. Kemampuan peserta pelatihan dalam penguasaan materi pemanfaatan kerajinan sampah bungkus minuman masih kurang karena waktu yang terbatas, namun setidaknya ada peningkatan pengetahuan dari yang dulunya tidak tahu menjadi tahu.

d. Program pengabdian berhasil memberdayakan perempuan atau ibu rumah tangga yang tidak bekerja untuk memanfaatkan sampah bungkus minuman menjadi barang yang bisa digunakan kembali.

e. Dalam kegiatan tanya jawab ada beberapa pertanyaan yang diajukan oleh para peserta pelatihan, antara lain:

1) Keuntungan dan kelemahan dari pemanfaatan sampah bungkus minuman menjadi produk bernilai ekonomis.

2) Adanya pelatihan bekelanjutan, misalnya pelatihan pengolahan sampah dengan metode yang lain seperti pemanfaatan sampah rumah tangga menjadi pupuk kompos.

\section{Pembahasan Hasil Pelaksanaan Kegiatan Pengabdian}


Pelaksanaan program pengabdian di RW 05 Kelurahan Bukit Tempayan, Kecamatan Batu Aji, Kota Batam berjalan dengan baik. Program pengabdian berupa pelatihan pengelolaan sampah rumah tangga dengan pemanfaatan sampah bungkus minuman dengan kerajinan perlu terus diupayakan mengingat produksi sampah rumah tangga yang semakin banyak. Hal ini dipicu dengan rendahnya kesadaran 3R, yaitu reuse (memakai kembali barang bekas yang masih bisa dipakai), reduce (berusaha mengurangi sampah), dan recycle (mendaur ulang sampah agar dapat dimanfaatkan). Melihat kondisi ini menjadi pertimbangan untuk mencari cara yang tepat dalam mengelola sampah sehingga tidak mencemari lingkungan dan mampu memberikan keuntungan nyata bagi masyarakat (produktif).

Dalam rangka mencari penyelesaian masalah sampah secara tepat, maka pada kegiatan pengabdian ini dilakukan pelatihan pemanfaatan sampah bungkus minuman menjadi barang yang bermanfaat. Adapun cara kerja dalam kerajinan dari sampah bungkus minuman yang dilakukan sebagai berikut:

1. Langkah pertama dalam pelatihan ini adalah menyiapkan bahan bungkus minuman atau kopi. Jumlah yang perlu disediakan adalah sekitar 100 - 500 bungkus tergantung seberapa besar kerajinan yang akan dibuat. Untuk dompet biasanya $100-200$ bungkus, sedangkan tas lebih dari 200 bungkus kopi tergantung ukuran tas yang akan dibuat.

2. Langkah berikutnya adalah menggunting bungkus kopi tersebut menjadi dua bagian, seperti pada gambar berikut ini:

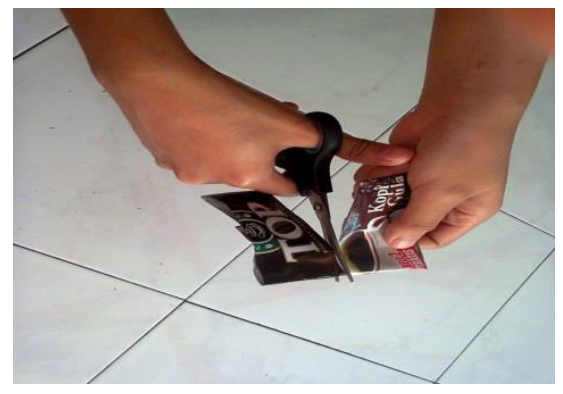

Gambar 1 Proses menggunting bungkus kopi

3. Langkah berikutnya adalah melipat pinggiran bungkus kopi ke dalam hingga rapi seperti gambar di bawah ini. 


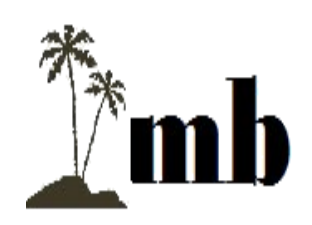

Doi.10.33373/jmb.v2i1.2271

E-ISSN 2614-5944

Minda Baharu, Volume 2, No 1 Juli 2018

Hal. 20-31
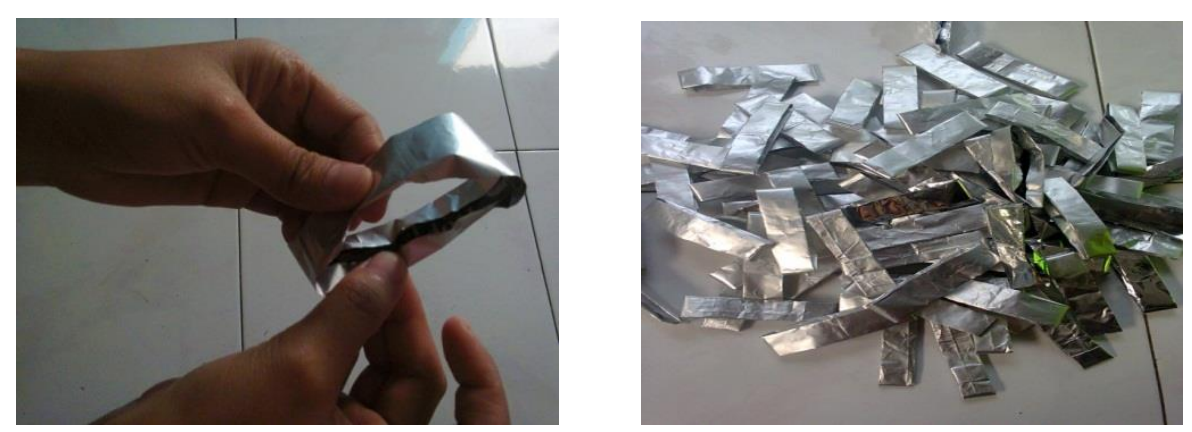

Gambar 2 Lipatan Bungkus Kopi

4. Setelah semua bungkus kopi dilipat menjadi dua, langkah berikutnya adalah proses menganyam bungkus kopi tersebut menjadi sebuah tas. Proses menganyam akan dijelaskan pada gambar berikut ini.
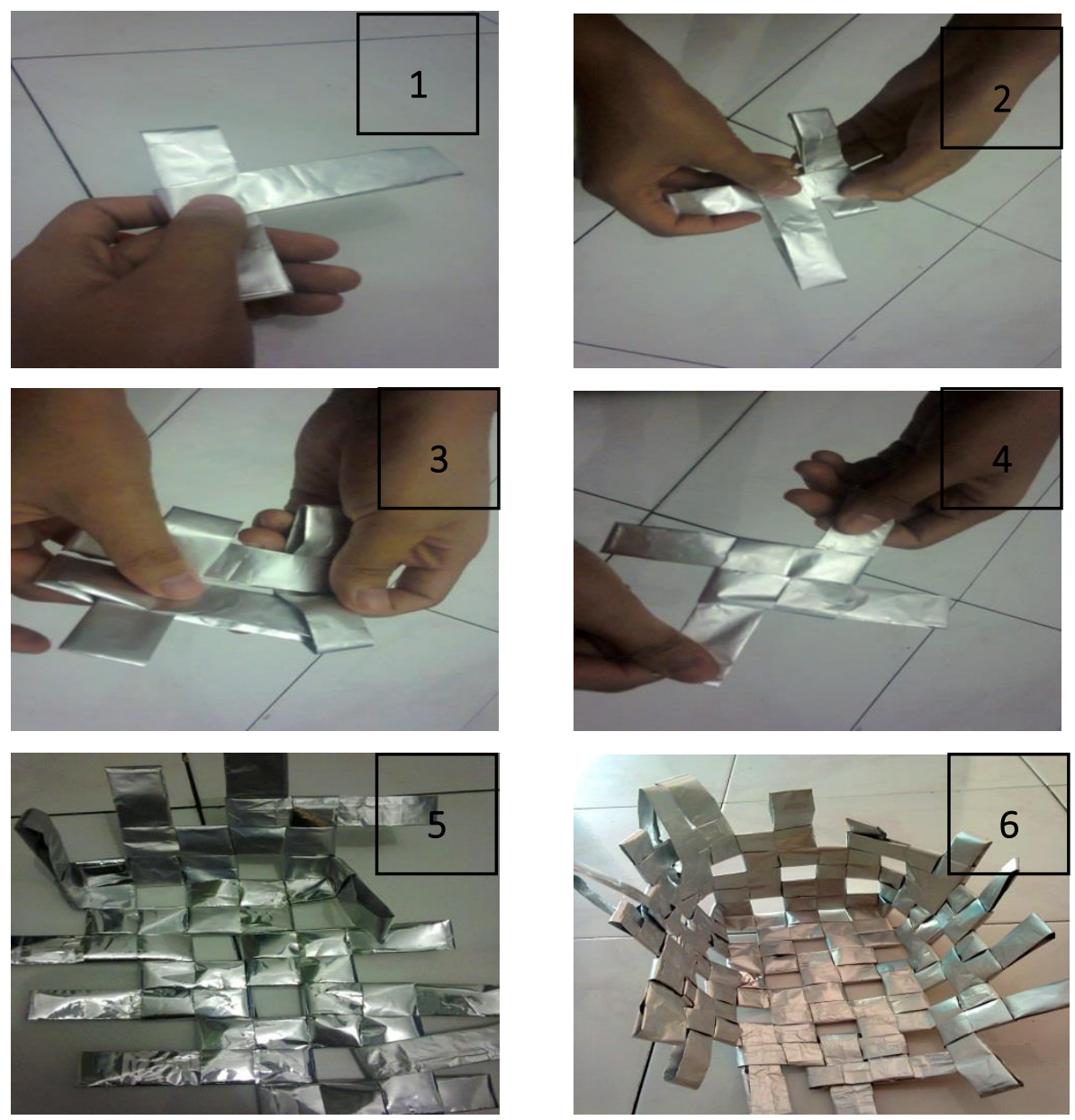


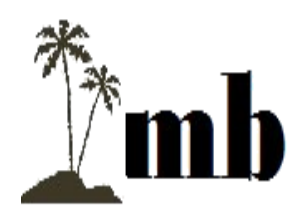

Doi.10.33373/jmb.v2i1.2271

E-ISSN 2614-5944

Minda Baharu, Volume 2, No 1 Juli 2018

Hal. 20-31
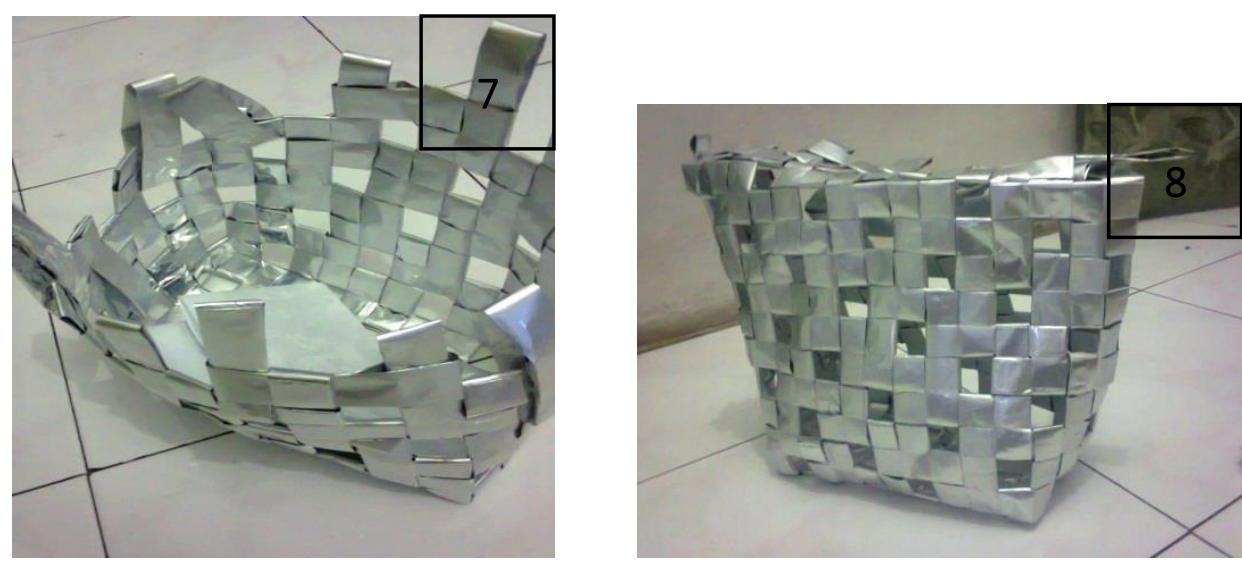

Gambar 3.Proses Menganyam Bungkus Kopi

5. Setelah proses menganyam selesai, maka berikut ini produk atau barang hasil

kerajinan dari sampah bungkus kopi tersebut.
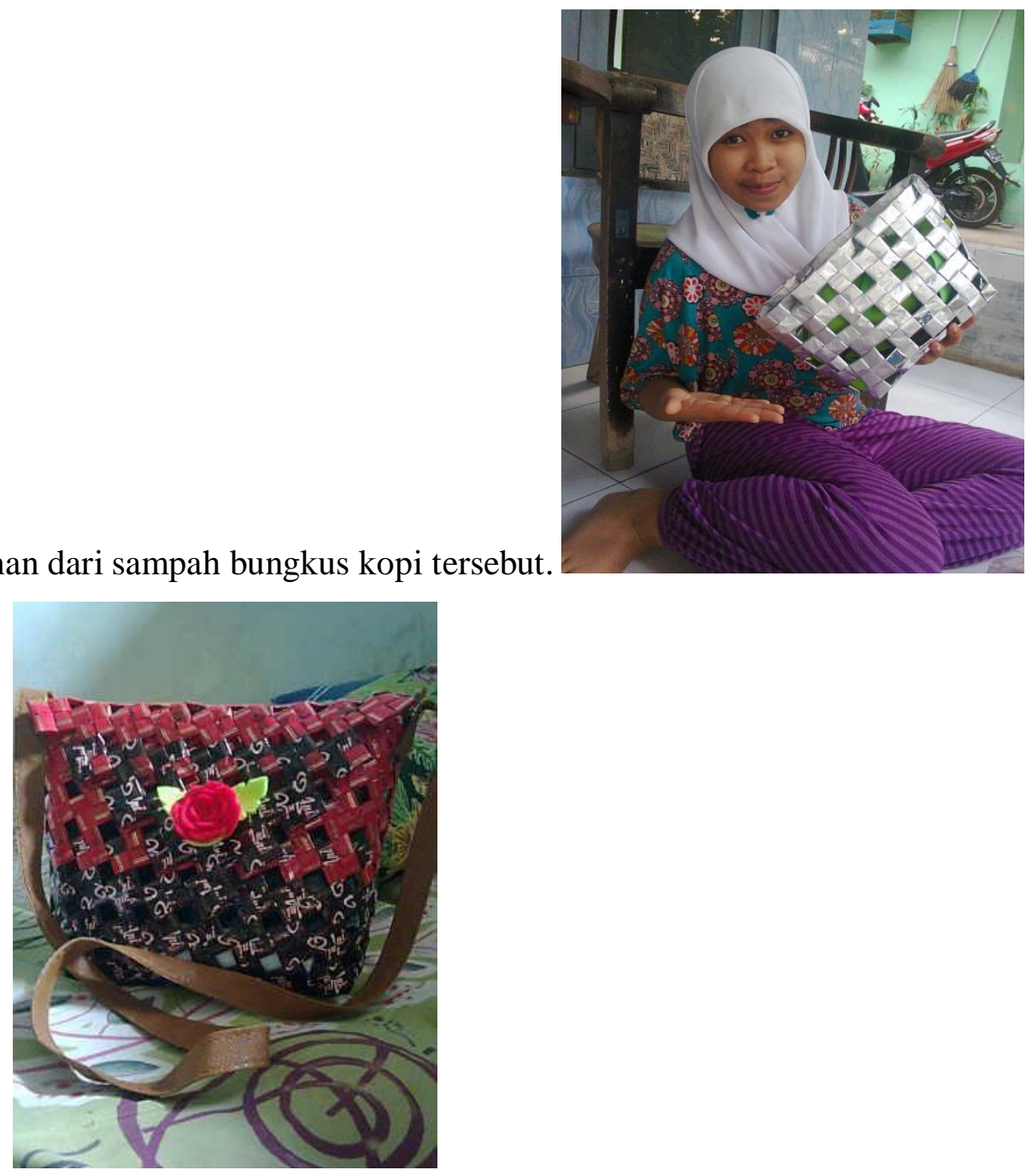


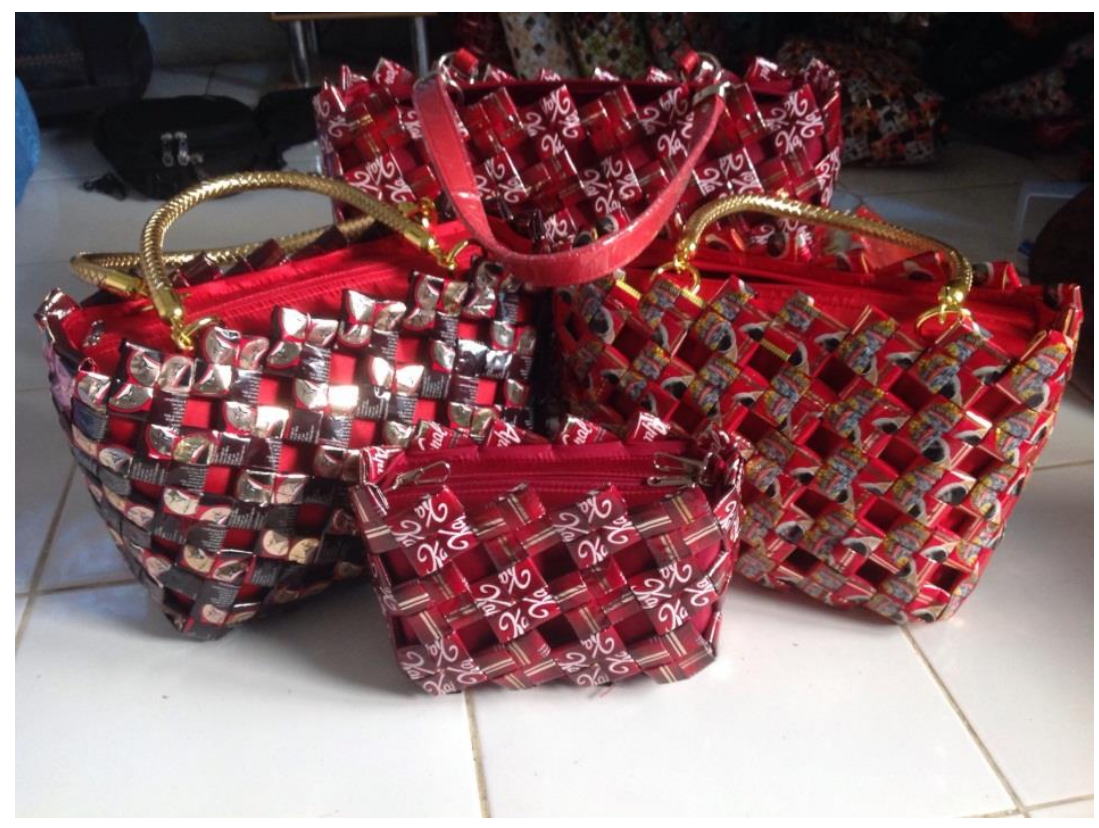

Gambar 4. Hasil Produk Anyaman Bungkus Kopi

Hasil kegiatan Abdimas Unrika secara garis besar dapat dilihat berdasarkan beberapa komponen berikut.

1. Keberhasilan target jumlah peserta pelatihan

Keberhasilan target jumlah peserta pelatihan dapat dikatakan sangat baik, mengingat target jumlah peserta pelatihan sebanyak 30 orang dan dalam pelaksanaan kegiatan dapat hadir sebanyak 30 orang (100\%). Hal ini didukung peran Ibu PKK RW 05 mulai dari persiapan, penyebaran undangan, pengadaan konsumsi, tempat dan peralatannya.

2. Ketercapaian tujuan pelatihan

Ketercapaian tujuan pelatihan dapat dikatakan baik (80\%), hal ini dikarenakan adanya peningkatan pengetahuan dari peserta, setidaknya dari yang dulunya tidak tahu menjadi tahu dan kegiatan pengabdian ini berhasil memberdayakan perempuan atau ibu rumah tangga di RW 05 Bukit Tempayan untuk lebih produktif dengan memanfaatkan sampah bungkus kopi atau minuman menjadi suatu produk yang bermanfaat dan bisa juga menambah pendampatan.

3. Ketercapaian target materi yang telah direncanakan

Ketercapaian target materi yang telah direncanakan pada kegiatan Abdimas ini dapat dikatakan baik (80\%), karena materi pelatihan dapat disampaikan secara keseluruhan 
meskipun tidak secara detil karena keterbatasan waktu. Materi pelatihan yang telah disampaikan adalah konsep lingkungan hidup, klasifikasi sampah, peran serta perempuan dalam lingkungan hidup, dan pengelolaan sampah rumah tangga dengan cara kerajinan tangan.

4. Kemampuan peserta dalam penguasaan materi

Kemampuan peserta dalam penguasaan materi dapat dikatakan cukup (70\%), hal ini dikarenakan waktu yang terbatas dalam penyampaian materi dengan menggunakan metode ceramah dan demonstrasi serta didukung kemampuan para peserta yang berbeda dalam menyerap materi yang disampaikan.

Secara keseluruhan kegiatan pelatihan pengelolaan sampah rumah tangga dengan cara membuat kerajinan tangan dinilai berhasil. Keberhasilan ini selain diukur dari keempat komponen di atas, juga dapat dilihat dari kepuasan peserta setelah mengikuti kegiatan pelatihan. Manfaat yang dapat diperoleh para peserta pelatihan adalah memahami pengelolaan sampah rumah tangga dengan cara membuat kerajinan tangan sehingga dapat turut serta dalam menjaga kelestarian lingkungan.

\section{KESIMPULAN}

Berdasarkan uraian dalam pembahasan, maka dapat disampaikan kesimpulan mengenai kegiatan pengabdian masyarakat di RW 05 Bukit Tempayan sebagai berikut:

1. Pelatihan pengelolaan sampah rumah tangga dengan cara membuat kerajinan di lokasi pengabdian dapat meningkatkan pengetahuan perempuan khususnya ibu rumah tangga, setidaknya dari tidak tahu menjadi tahu serta berhasil memberdayakan perempuan untuk memanfaatkan sampah bungkus minuman atau kopi menjadi suatu produk yang bermanfaat dan bernilai ekonomis.

2. Peningkatan pemahaman bagi peserta pelatihan dilakukan dengan metode ceramah dan demonstrasi serta pemberian kesempatan untuk tanya jawab.

\section{REFERENSI}

Damanhuri, E., dkk. 2004. Diktat Kuliah Pengelolaan Sampah. Edisi Semester I 2004/2005. Bandung: ITB. 
Doddy Ari S., Diana S., 2005. Kajian Potensi Ekonomis dengan Penerapan $3 R$ (Reduce, Reuse, dan Recycle) Pada Pengelolaan Sampah Rumah Tangga di Kota Depok. Depok: Prosiding Seminar Ilmiah PESAT Universitas Gunardama.

Dyah Respati SS, dkk. 2008. Laporan Kegiatan PPM Dosen: Pelatihan dan Sosialisasi Pengelolaan Sampah Rumah Tangga Berbasis Budaya terhadap Guru Sekolah Dasar di Kecamatan Wirobrajan Menuju Kota Jogja Green and Clean. Yogyakarta: FISE UNY.

Karden Edy Sontang Manik. 2007. Pengelolaan Lingkungan Hidup. Jakarta: Penerbit Djambatan.

Kuncoro Sejati. 2009. Pengolahan Sampah Terpadu. Yogyakarta: Kanisius.

Undang-Undang Republik Indonesia Nomor 18 Tahun 2008 tentang Pengelolaan Sampah.

Undang-Undang Republik Indonesia Nomor 32 Tahun 2009 tentang Perlindungan dan Pengelolaan Lingkungan Hidup.

Valentinus Darsono. 1995. Pengantar Ilmu lingkungan. Yogyakarta: Penerbit Universitas Atma Jaya. 